\title{
Distributions of inorganic nitrogen and biological production in the equatorial Pacific: a basin-scale model sensitivity study of nitrification
}

\author{
Xiujun Wang ${ }^{1,2,3^{*}}$ and Raghu Murtugudde ${ }^{3}$
}

\begin{abstract}
Recent evidence indicates that there is stronger nitrification in the euphotic zone than previously thought. We employ a physical-biogeochemical model to study the implications of nitrification for basin-scale distributions of nitrate, ammonium, and biological production in the equatorial Pacific. The model can faithfully reproduce observed features in nitrate distribution, with or without photoinhibition of nitrification in the euphotic zone. In addition, new production, net community production and export production are not very sensitive to the parameterization of nitrification in this model. However, simulated ammonium distribution, nitrate uptake and ammonium uptake are sensitive to this parameterization. High nitrification results in low ammonium concentration, low ammonium uptake rate, and high nitrate uptake rate in the euphotic zone. This study suggests that nitrification may be responsible for up to $40 \%$ of nitrate uptake in the equatorial Pacific. This modeling study also demonstrates large differences (in terms of the magnitude and spatial distribution) between nitrate uptake, new production and export production, reflecting decoupling of upward nutrient supply, biological uptake and downward export.
\end{abstract}

Keywords: Nitrogen; Nitrification; Biogeochemical model; Equatorial Pacific

\section{Background}

The equatorial Pacific Ocean is the largest oceanic source of carbon dioxide $\left(\mathrm{CO}_{2}\right)$ to the atmosphere [1]. The strong outgassing is partly attributable to the low efficiency of the "biological pump", i.e., the export of particulate organic materials from surface waters to the deep ocean. Thus, studying the "biological pump" is critical to our understanding of the carbon cycle. Due to the difficulty in measuring export production, an alternative approach, measuring new production, has been employed to determine the magnitude of the "biological pump". In a steady state, new production, defined as uptake of preformed nitrogen (primarily nitrate) that is transported from deep waters into the euphotic zone, should equal to export production $[2,3,4]$.

In practice, new production is often determined by measuring nitrate consumption by phytoplankton. This

\footnotetext{
* Correspondence: wwang@essic.umd.edu

${ }^{1}$ College of Global Change and Earth System Science, Beijing Normal University, Xinjiekouwai Street No.19, Haidian District, Beijing 100875, China ${ }^{2}$ Joint Center for Global Change Studies, Beijing 100875, China

Full list of author information is available at the end of the article
}

approach may lead to overestimation due to nitrification (i.e., oxidation of ammonium to nitrate) in the euphotic zone [5] because there is strong evidence of nitrification in the euphotic zone of the global ocean $[6,7,8,3,9]$. For example, a field study shows considerable nitrification in the euphotic zone of the equatorial Pacific, especially in the strong upwelling region [6]. However, early studies provided evidence of photoinhibition of marine nitrifying bacteria (e.g., $[10,11])$. Therefore, photoinhibition has traditionally been applied to nitrification in many biogeochemical models (e.g., $[12,13,14,15,16])$. Yet, there has not been much attention paid to the implication of nitrification for estimating new production until recently $[3,9]$.

While one may conclude that the nitrate consumption approach to estimating new production leads to an overestimation of the magnitude of new production and the efficiency of the "biological pump" due to nitrification in the euphotic zone, the process of nitrification itself is still not fully understood. Our understanding of the factors that influence nitrification is limited, partly due to the inconsistencies among methodologies [3], and also, 
probably attributable to the uncertainties of measuring ammonium oxidation [9]. Using available observational studies, Yool et al. [3] derived a large range of the specific nitrification rate, from $<0.0$ to $>1 \mathrm{~d}^{-1}$. This range is not only because of techniques and designs, and also because of natural temporal and spatial variability. However, most biogeochemical models (e.g., $[13,14,15,16]$ ) apply a relatively low rate, ranging from 0.02 to $0.1 \mathrm{~d}^{-1}$ with photoinhibition in the euphotic zone. Clearly, not only more observations are warranted to better understand nitrification and associated processes, but there is also a need for further modeling studies to assess the implications of different specific nitrification rates for the nitrogen cycle in the upper ocean.

Here, we use a fully coupled physical-biogeochemical model to address this issue in the equatorial Pacific which has large spatio-temporal contrasts in physical and biogeochemical fields. Our approach includes the use of observations for integrated model assessments of nitrate, ammonium, nitrate consumption, and total nitrogen uptake. We present model-data comparisons of nitrate and ammonium to test different nitrification scenarios. The objective of this study is to assess if nitrate uptake can represent new production or export production and what the implications of nitrification are for the equatorial Pacific.

\section{Methods}

A 3-dimensional physical-biogeochemical model has been developed for the equatorial Pacific. The ocean general circulation model (OGCM) is based on a primitive equation, $\sigma$-coordinate model that is coupled to an advective atmospheric mixed layer model [17]. The model is forced by solar radiation, cloudiness, surface wind stresses, wind speeds and precipitation, but the air temperature and humidity are computed by an advective atmospheric mixed layer model coupled to the OGCM so that sea surface temperature (SST) can be determined interactively without prescribing the latent and sensible heat fluxes and long wave radiation. The solar radiation and cloudiness are climatological monthly means, and precipitation is interannually varying six-day means. We also use interannual, six-day means of the surface wind stresses and wind speeds (1978-2007). All the forcing data were obtained from the National Centers for Environmental Prediction (NCEP) reanalysis [18].

The biogeochemical model consists of ten components: seven biological pools and three nutrients (ammonium, nitrate, and dissolved iron) pools (Figure 1). The biological pools include dissolved organic nitrogen, and two sizes (large and small) of phytoplankton, zooplankton and detritus, respectively. Model equations and biological parameters are described in Wang et al. [19]. The biogeochemical model is a nitrogen-based model with iron limitation. Phytoplankton growth (thus nitrogen uptake) is a function of nitrogen, iron, temperature and light conditions. Parameterizations of nitrogen uptake and regeneration were described by Wang et al. [20]. Our modeling effort has included extensive use of observational data for model calibration and validation; e.g., dissolved and particulate organic nitrogen [19], basinscale chlorophyll distribution [21], nitrate and ammonium uptake, and ammonium regeneration [20].

Here, we carry out a sensitivity experiment to test the implication of nitrification for the nitrogen cycle, using commonly used range of specific nitrification rate in most biogeochemical models (e.g., $[16,13])$. The sensitivity study consists of four simulations: standard, NITR1, NITR2 and NITR3. For the standard simulation, nitrification $\left(0.04 \mathrm{~d}^{-1}\right)$ occurs only below the euphotic zone. For the NITR1, nitrification rate is constant $\left(0.02 \mathrm{~d}^{-1}\right)$ throughout the water column. The NITR2 experiment has a low rate $\left(0.02 \mathrm{~d}^{-1}\right)$ for the euphotic zone, and high rate $\left(0.06 \mathrm{~d}^{-1}\right)$ below the euphotic zone. The NITR3 has a constant specific nitrification rate of $0.06 \mathrm{~d}^{-1}$ throughout the water column. The experiment allows us to compare ammonium and nitrate concentrations and their uptake rates with (the standard and NITR2) and without (the NITR1 and NITR3) photoinhibition of nitrification in the euphotic zone.

\section{Results}

To assess the basin-scale consequences of nitrification, we compared the climatology of nitrate for the equatorial Pacific Ocean between the model simulations and observations from the World Ocean Database [22]. There were only minor differences in the surface nitrate among the four simulations (Figure 2). These results indicated that modeled nitrate was not highly sensitive to the parameterization of nitrification commonly used in the biogeochemical models, which was also noted by Mongin et al. [23]. Overall, the model, with or without photoinhibition of nitrification, reproduced many observed features of nitrate, including the spatial pattern and magnitude. For instance, both data and model simulations (Figure 2a and $2 \mathrm{~b}$ ) showed much higher nitrate concentration in the eastern upwelling region $\left(\sim 10 \mathrm{mmol} \mathrm{m}^{-3}\right)$ relative to the western warm pool $\left(0-1 \mathrm{mmol} \mathrm{m}^{-3}\right)$, and also the equatorial asymmetry (i.e., high concentration to the south of the equator).

Physical and biogeochemical parameters were measured during the EBENE cruise (October-November, 1996 ) along $180^{\circ}$ in the equatorial Pacific (see introduction by [24]). Specifically, intensive sampling of nitrate and ammonium profiles was carried out at the equator and $3^{\circ} \mathrm{S}$ for five days [25]. Figure 2 shows the observed nitrate and ammonium profiles against simulated profiles from the sensitivity study for the upper $200 \mathrm{~m}$ of the water column. Observations show similar values for 


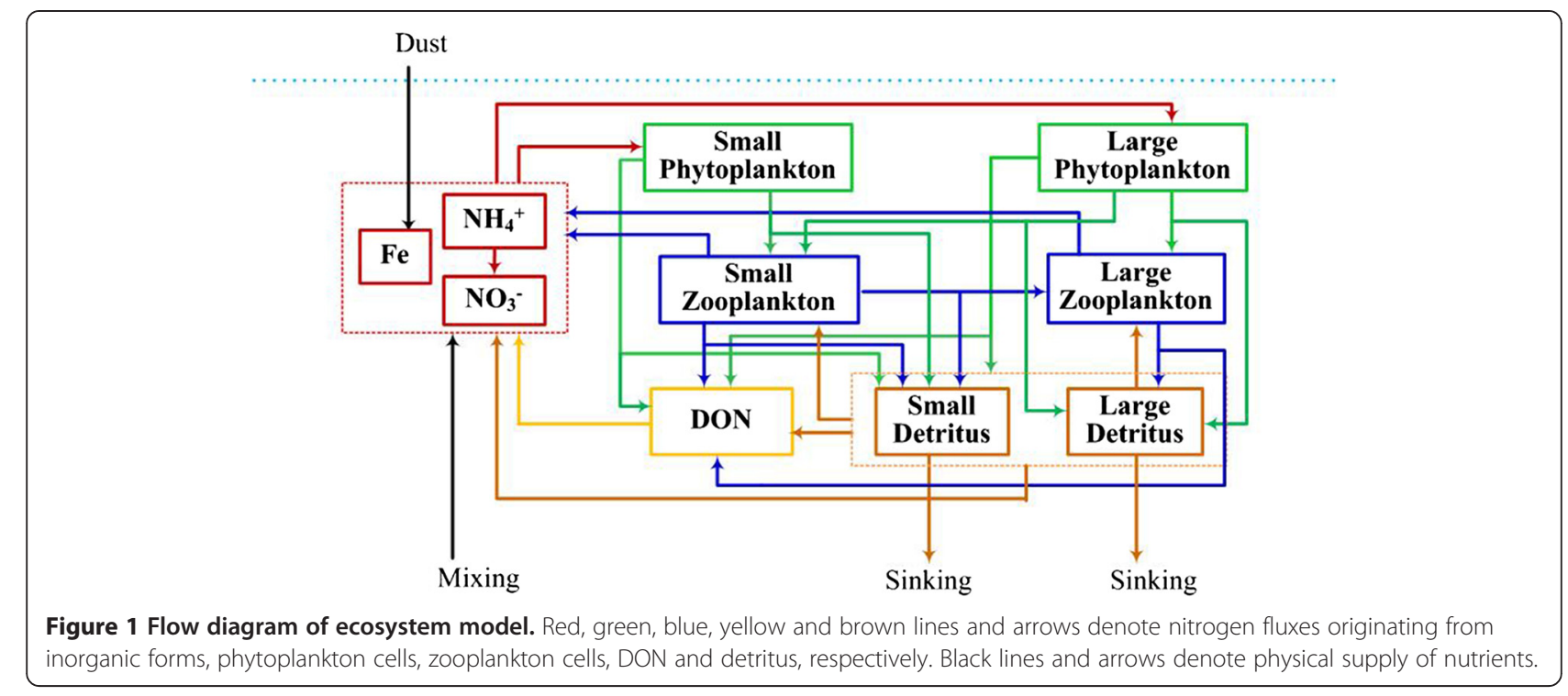

nitrate and ammonium in surface waters at both locations but considerable differences in the subsurface, particularly at $\sim 100 \mathrm{~m}$. The observed subsurface nitrate concentration was higher at the equator than at $3^{\circ} \mathrm{S}$ whereas the observed subsurface ammonium concentration was lower at the equator than at $3^{\circ} \mathrm{S}$. The decoupling between ammonium and nitrate was mainly a result of upwelling that brings up high-nitrate-low-ammonium water from deep layer. There were other studies showing similar features in ammonium distribution in the equatorial Pacific, particularly stronger deep ammonium maxima (DAM) off the equator than on the equator $[26,27,28]$.

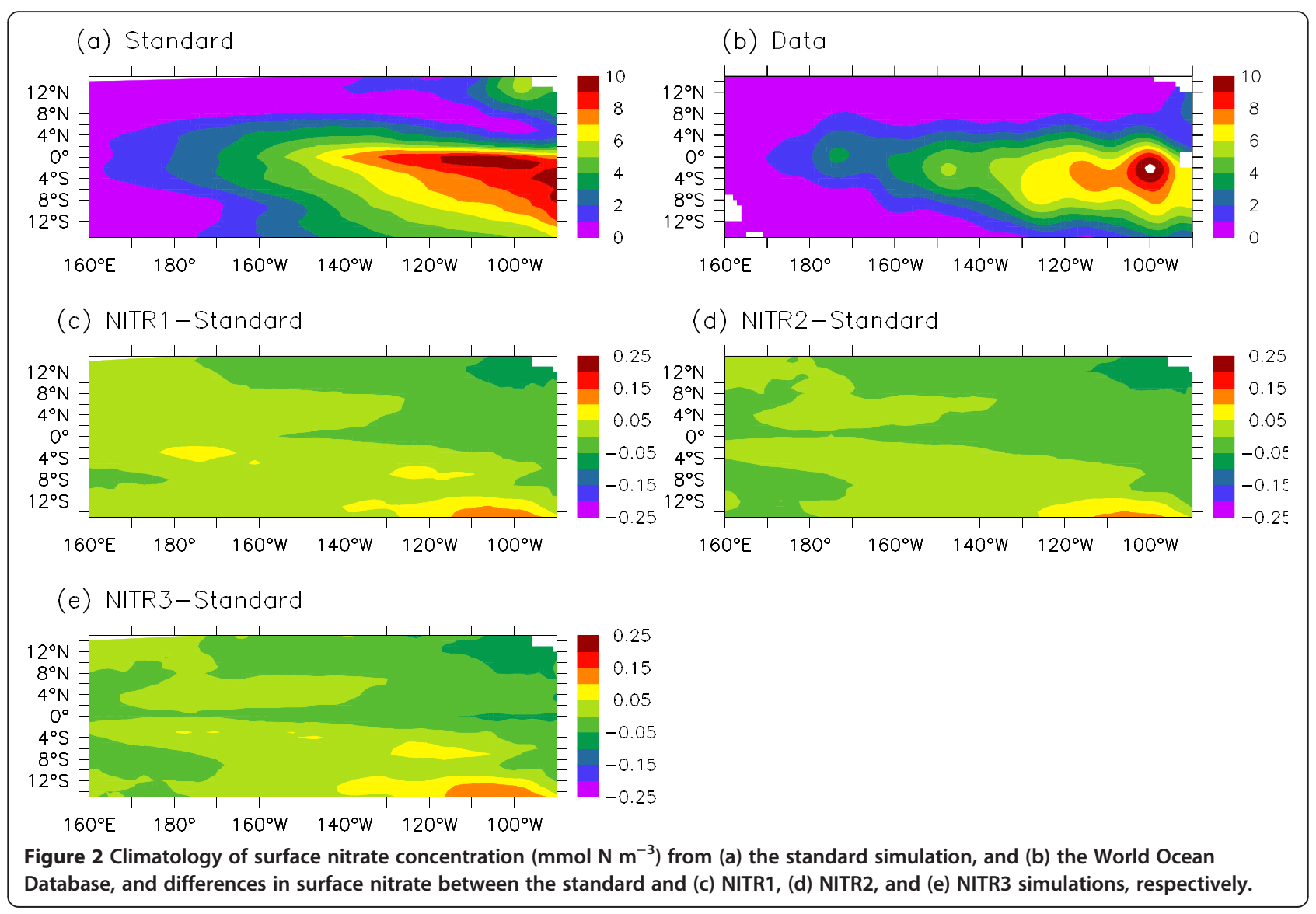


Modeled nitrate profiles were similar among the four simulations albeit slightly higher in concentrations than the observations. The model-data mismatch in nitrate is mainly obvious at $3^{\circ} \mathrm{S}$, particularly below the surface where modeled nitrate concentrations are approximately $3 \mathrm{mmol} \mathrm{m}^{-3}$ higher than the observations. Unlike nitrate, ammonium profiles show pronounced differences among the four model simulations (Figure 2c and 2d). Apparently, the standard simulation with zero-nitrification produces the highest ammonium concentrations in the euphotic zone, which are nearly $100 \%$ higher than the observations. As expected, modeled ammonium concentration decreases with increasing specific nitrification rate. For instance, the NITR3 simulation with the highest specific nitrification rate $\left(0.06 \mathrm{~d}^{-1}\right)$ produces the lowest ammonium concentration. The simulated ammonium profile from the NITR3 run shows only a weak DAM, and small spatial differences in concentration between the equator and $3^{\circ} \mathrm{S}$. It appears that the application of specific nitrification rate of $0.06 \mathrm{~d}^{-1}$ slightly underestimates the subsurface ammonium concentration. On the other hand, the NITR1 simulation, applied with the lowest specific nitrification rate $\left(0.02 \mathrm{~d}^{-1}\right)$ below the euphotic zone, shows a pronounced overestimation of ammonium concentration below $120 \mathrm{~m}$.
Previously, a modeling study showed that increasing nitrification rate from $0.02 \mathrm{~d}^{-1}$ to $0.2 \mathrm{~d}^{-1}$ resulted in a significant increase $(>60 \%)$ in the global nitrate uptake but relatively no increase in the total primary production [3]. Figure 3 shows comparisons of the total nitrogen uptake, nitrate uptake, export production and net community production between the standard and NITR3 simulations for the equatorial Pacific. While the total nitrogen uptake was not expected to change (see details in [20]), our results also show little change in export production and net community production. However, there is a pronounced increase $(20-50 \%)$ in the integrated nitrate uptake in the euphotic zone when nitrification rate is increased from 0 to $0.06 \mathrm{~d}^{-1}$.

Table 1 presents comparisons of nitrogen fluxes between the standard and NITR3 simulations in the Wyrtki box $\left(5^{\circ} \mathrm{N}-5^{\circ} \mathrm{S}, 180^{\circ}-90^{\circ} \mathrm{W}\right)$. Relative to the standard simulation, the NITR3 produces significantly higher rate of nitrate uptake $\left(0.97 \mathrm{mmol} \mathrm{N} \mathrm{m}^{-2} \mathrm{~d}^{-1}\right)$, but lower rate of ammonium uptake $\left(0.99 \mathrm{mmol} \mathrm{N} \mathrm{m}^{-2} \mathrm{~d}^{-1}\right)$. However, the differences of the total nitrogen uptake, new production and export production are extremely small between the two simulations. Estimated rates of new production and export production show some degree of
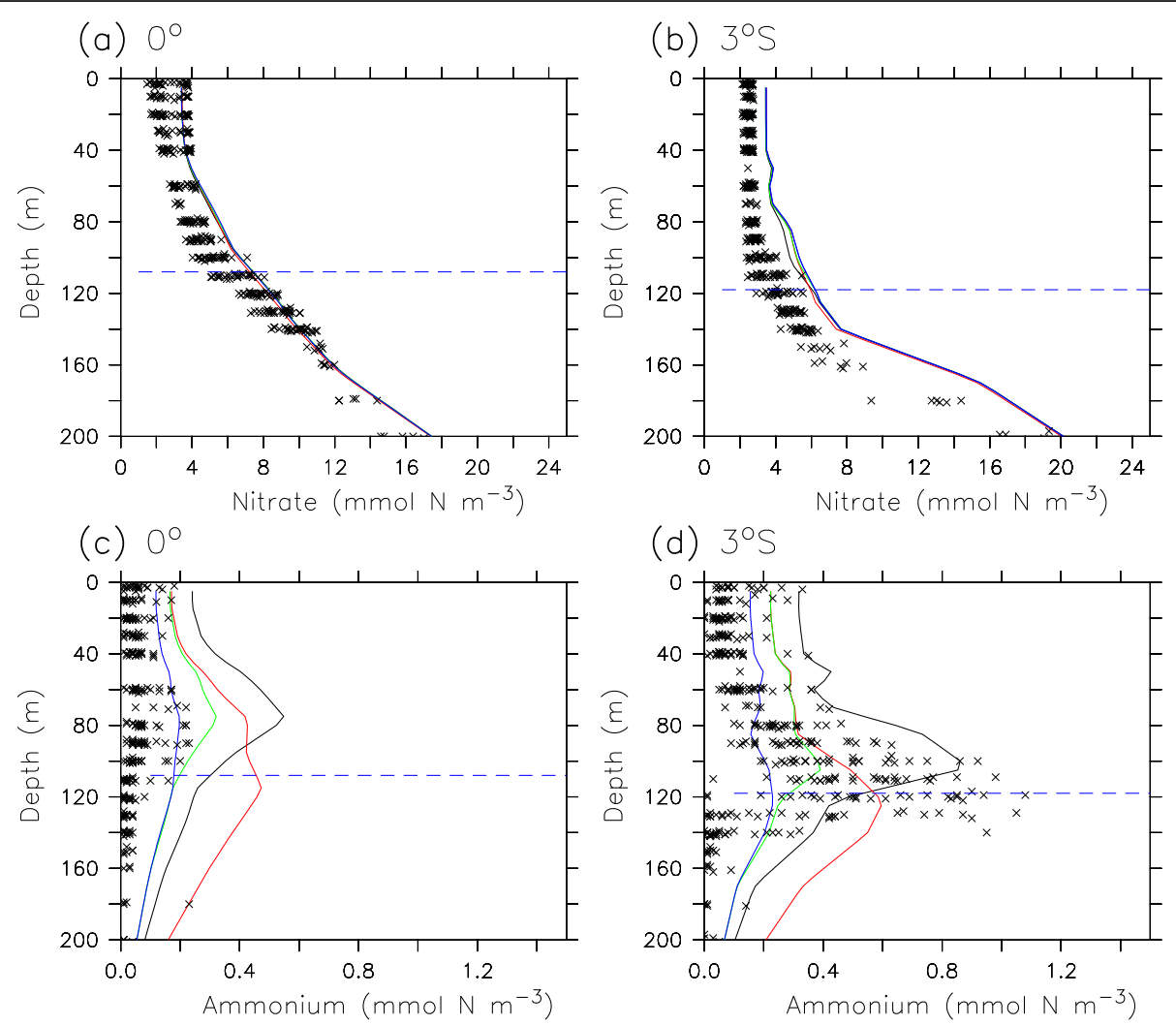

Figure 3 Profiles of (a) and (b) nitrate, and (c) and (d) ammonium at $0^{\circ}$ (left panel) and $3^{\circ} \mathrm{S}$ (right panel) along $180^{\circ}$ during October-November, 1996. Symbols denote data [8]. Lines represent model simulation for the standard (black), NITR1 (red), NITR2 (green) and NITR3 (blue). Dashed lines indicate the euphotic depth. 


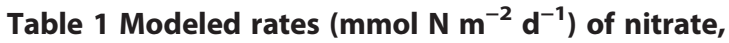
ammonium and total $\mathrm{N}$ uptake, nitrification, new production, and export production during 1990-2000 in the Wyrtki box $\left(5^{\circ} \mathrm{N}-5^{\circ} \mathrm{S}, 180^{\circ}-90^{\circ} \mathrm{W}\right)$

\begin{tabular}{|c|c|c|c|c|}
\hline & \multicolumn{2}{|c|}{ Standard } & \multicolumn{2}{|l|}{ NITR3 } \\
\hline & $5^{\circ} \mathrm{N}-0^{\circ}$ & $0^{\circ}-5^{\circ} \mathrm{S}$ & $5^{\circ} \mathrm{N}-0^{\circ}$ & $0^{\circ}-5^{\circ} \mathrm{S}$ \\
\hline Nitrate uptake & 1.90 & 1.90 & 2.87 & 2.87 \\
\hline Ammonium uptake & 6.83 & 6.43 & 5.84 & 5.45 \\
\hline Total N uptake & 8.73 & 8.33 & 8.71 & 8.32 \\
\hline Nitrification & 0.22 & 0.19 & 1.27 & 1.17 \\
\hline New production* & 1.68 & 1.71 & 1.60 & 1.70 \\
\hline Export production at $120 \mathrm{~m}$ & 1.14 & 1.08 & 1.14 & 1.08 \\
\hline
\end{tabular}

*New production $=$ nitrate uptake - nitrification.

asymmetries although the integrated rate of nitrate uptake shows no asymmetry (Figure 4). Interestingly, new production is higher to the south than to the north in the eastern equatorial Pacific whereas export production is the highest to the north in the central equatorial
Pacific. The former reflects higher biological production (nutrient uptake) to the south as a result of stronger upwelling [24] whereas the latter reflects horizontal export of organic materials to outside of the strong upwelling region. As shown in Table 1, the rate of new production $\left(1.7 \mathrm{mmol} \mathrm{N} \mathrm{m}^{-2} \mathrm{~d}^{-1}\right)$ is considerably higher than the rate of export production $\left(1.1 \mathrm{mmol} \mathrm{N} \mathrm{m}^{-2} \mathrm{~d}^{-1}\right)$ in the Wyrtki box, indicating $35 \%$ of new production is exported to elsewhere.

\section{Discussion and conclusion}

The mean and median specific nitrification rates are $0.55 \mathrm{~d}^{-1}$ and $0.195 \mathrm{~d}^{-1}$, respectively, as estimated from the sparse observations in the global ocean [3]. Biogeochemical models typically apply a constant specific nitrification rate, ranging from 0.02 to $0.1 \mathrm{~d}^{-1}$ with photoinhibition in the euphotic zone $[16,15,13,14]$. While this study shows that such a low rate may be a reasonable average over large scales, it is questionable whether measured nitrification rate at a specific time

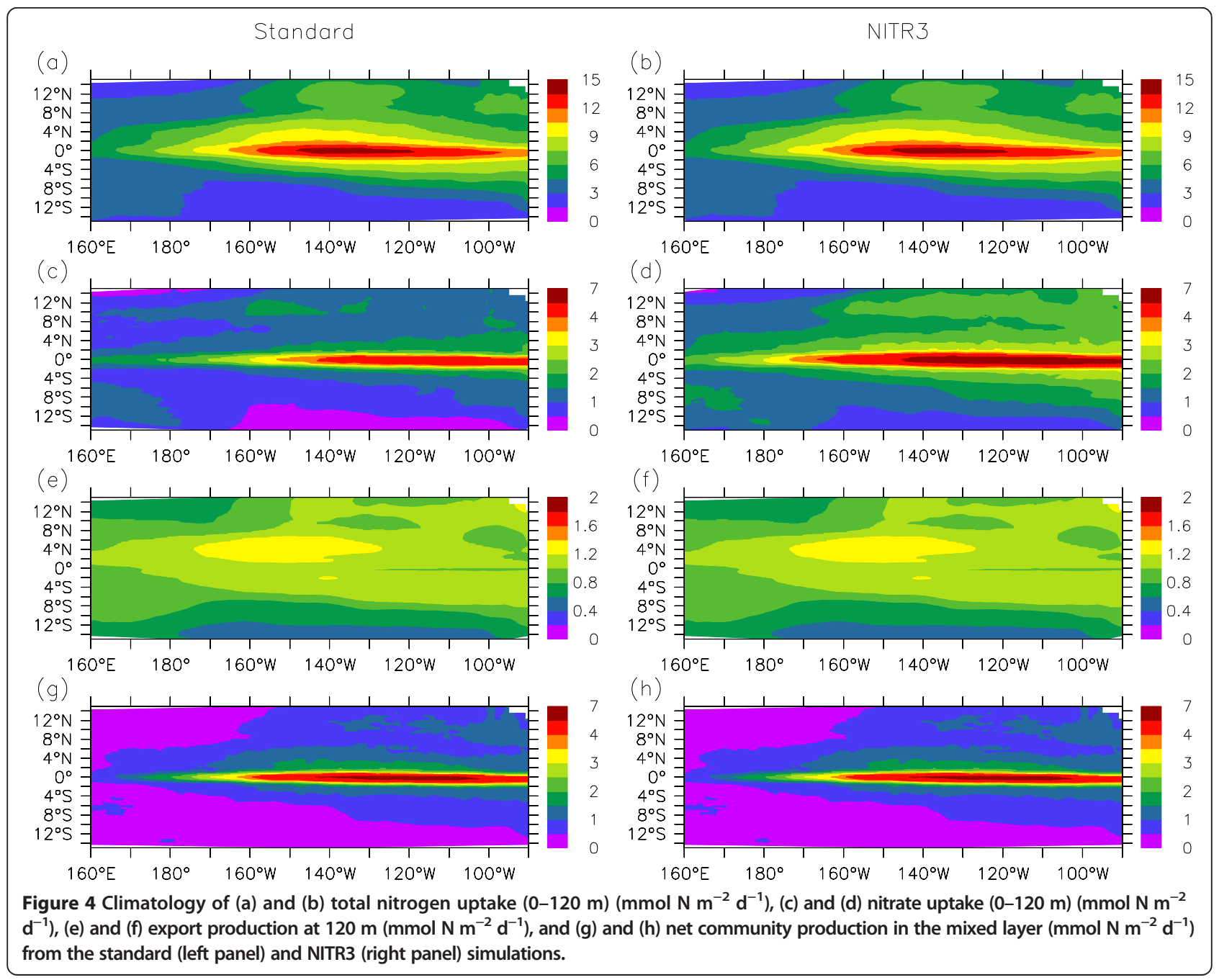


under certain conditions can be applied linearly over basin scales. On the one hand, a better parameterization of the nitrification process (e.g., non-linear relationship to ammonium concentration) is essential for biogeochemical models to improve model skills [29]. On the other hand, more field studies are needed to provide insights for modeling the nitrification process; e.g., regulatory factors and mechanisms.

Biogeochemical model validations often focus on nitrate distribution, largely driven by data availability. This study indicates that modeled nitrate distribution is not very sensitive to some parameterizations (e.g., nitrification). Ammonium, revealing considerable spatial and temporal variations with relatively low concentrations, may provide a sensitive and realistic check on the performance of biogeochemical models [30]. Moreover, an approach with integrated validations of concentrations and uptake rates of both nitrate and ammonium would provide an overall assessment on biogeochemical model skills [20], which requires integrated observations of different nitrogen forms and fluxes such as Raimbault et al. [6].

There is a large range $\left(\sim 0.01 \mathrm{~d}^{-1}\right.$ to $\left.>1 \mathrm{~d}^{-1}\right)$ in the specific nitrification rate [3], which is derived from the daily rate of ammonium oxidation divided by the ambient ammonium concentration. The former, reflecting microbiological activity, is regulated by environmental conditions whereas the latter is affected by the processes involving the generation and removal of ammonium. Thus, field measurements remain difficult and may introduce potential errors and uncertainties because simultaneous processes may interfere with rate measurements [8]. Clearly, further studies with advanced methodology are needed not only to determine the specific nitrification rate, but also to better understand the regulating processes, i.e., the controlling of light, temperature and other factors. Moreover, studies of other associated processes (e.g., ammonium uptake and inhibition) would advance our understanding of the marine nitrogen cycle.

Many studies have shown that nitrification is not negligible in the euphotic zone of the global ocean. For example, a recent field study demonstrated that nitrification in the euphotic zone could support 3-100\% of nitrate uptake (e.g., [5]) . This study suggests that nitrification may be responsible for up to $40 \%$ of nitrate uptake in the equatorial Pacific. There are large differences in magnitude and spatial distribution between nitrate uptake, new production and export production, suggesting that the classic assumption of upward flux of nitrate equal to downward flux of sinking organic nitrogen may not be applicable in the real ocean where three-dimensional activities decouple the associated processes, i.e., upward inorganic nutrient supply, biological uptake in the euphotic zone, and downward export of organic materials [31]. Therefore, the traditional view of "a steady state" ocean may not be applied to small-scale regions. The present study is obviously only the first step in demonstrating the importance of parameterization of nitrification in models. Further studies with longer simulations are needed to demonstrate larges implication of nitrification on seasonal-to-interannual and longer timescale variability of new production.

\section{Competing interests}

The authors declare that they have no competing interests.

\section{Authors' contributions}

RM helped with model setting, and XW carried out the model experiments. Both authors wrote and approved the final manuscript.

\section{Acknowledgements}

This work is supported by grants from the National Key Basic Research Program (2013CB956602). The authors wish to acknowledge use of the Ferret program for analysis and graphics in this paper. Ferret is a product of NOAA's Pacific Marine Environmental Laboratory (Information is available at http://ferret.pmel.noaa.gov/Ferret/).

\section{Author details}

${ }^{1}$ College of Global Change and Earth System Science, Beijing Normal University, Xinjiekouwai Street No.19, Haidian District, Beijing 100875, China. 2Joint Center for Global Change Studies, Beijing 100875, China. ${ }^{3}$ Earth System Science Interdisciplinary Center, University of Maryland, 5815 University Research Ct, Ste 4001, College Park, MD 20740, USA.

Received: 12 August 2014 Accepted: 14 February 2015

Published online: 03 March 2015

\section{References}

1. Feely RA, Boutin J, Cosca CE, Dandonneau Y, Etcheto J, Inoue HY, Ishii M, Quéré CL, Mackey DJ, McPhaden M, Metzl N, Poisson A, Wanninkhof R (2002) Seasonal and interannual variability of CO2 in the equatorial Pacific. Deep Sea Research Part II 49:2443-2469

2. Wang XJ, Murtugudde R, Busalacchi AJ, Le Borgne R (2005) De-coupling of net community production and new production in the euphotic zone of the equatorial Pacific: A model study. Geophysical Research Letters 32: L21601, 21610.21029/22005GL024100

3. Yool A, Martin AP, Fernandez C, Clark DR (2007) The significance of nitrification for oceanic new production. Nature 447:999-1002

4. Eppley RW, Peterson BJ (1979) Particulate organic-matter flux and planlktonic new production in the deep ocean. Nature 282:677-680

5. Grundle DS, Juniper SK, Giesbrecht KE (2013) Euphotic zone nitrification in the NE subarctic Pacific: Implications for measurements of new production. Marine Chemistry 155:113-123

6. Raimbault P, Slawyk G, Boudjellal B, Coatanoan C, Conan P, Coste B, Garcia N, Moutin T, Pujo-Pay M (1999) Carbon and nitrogen uptake and export in the equatorial Pacific at 150 degrees W: Evidence of an efficient regenerated production cycle. Journal of Geophysical Research 104:3341-3356

7. Dore JE, Karl DM (1996) Nitrification in the euphotic zone as a source for nitrite, nitrate, and nitrous oxide at Station ALOHA. Limnology and Oceanography 41:1619-1628

8. Wankel SD, Kendall C, Pennington JT, Chavez FP, Paytan A (2007) Nitrification in the euphotic zone as evidenced by nitrate dual isotopic composition: Observations from Monterey Bay, California. Global Biogeochemical Cycles 21: GB2009, doi:2010.1029/2006GB002723.

9. Clark DR, Rees AP, Joint I (2008) Ammonium regeneration and nitrification rates in the oligotrophic Atlantic Ocean: Implications for new production estimates. Limnology and Oceanography 53:52-62

10. Olson RJ (1981) Differential photoinhibition of marine nitrifying bacteria- A possible mechanism for the formation of the primary nitrite maximum. Journal of Marine Research 39:227-238

11. Guerrero MA, Jones RD (1996) Photoinhibition of marine nitrifying bacteria.1. Wavelength-dependent response. Marine Ecology-Progress Series 141:183-192

12. Denman $\mathrm{KL}$ (2003) Modelling planktonic ecosystems: parameterizing complexity. Progress in Oceanography 57:429-452 
13. Moore JK, Doney SC, Kleypas JA, Glover DM, Fung IY (2002) An intermediate complexity marine ecosystem model for the global domain. Deep-Sea Research Part II 49:403-462

14. Wang XJ, Christian JR, Murtugudde R, Busalacchi AJ (2006) Spatial and temporal variability in new production in the equatorial Pacific during 1980-2003: Physical and biogeochemical controls. Deep-Sea Research Part II 53:677-697

15. Christian JR, Verschell MA, Murtugudde R, Busalacchi AJ, McClain CR (2002) Biogeochemical modelling of the tropical Pacific Ocean. I: Seasonal and interannual variability. Deep-Sea Research Part II 49:509-543

16. Jiang MS, Chai F, Dugdale RC, Wilkerson FP, Peng TH, Barber RT (2003) A nitrate and silicate budget in the equatorial Pacific Ocean: a coupled physical-biological model study. Deep-Sea Research Part II 50:2971-2996

17. Murtugudde R, Seager R, Busalacchi A (1996) Simulation of the tropical oceans with an ocean GCM coupled to an atmospheric mixed-layer model. Journal of Climate 9:1795-1815

18. Kalnay E, Kanamitsu M, Kistler R, Collins W, Deaven D, Gandin L, Iredell M, Saha S, White G, Woollen J, Zhu Y, Chelliah M, Ebisuzaki W, Higgins W, Janowiak J, Mo KC, Ropelewski C, Wang J, Leetmaa A, Reynolds R, Jenne R, Joseph D (1996) The NCEP/NCAR 40-year reanalysis project. Bulletin of the American Meteorological Society 77:437-471

19. Wang XJ, Le Borgne R, Murtugudde R, Busalacchi AJ, Behrenfeld M (2008) Spatial and temporal variations in dissolved and particulate organic nitrogen in the equatorial Pacific: biological and physical influences. Biogeosciences 5:1705-1721

20. Wang XJ, Le Borgne R, Murtugudde R (2009) Nitrogen uptake and regeneration pathways in the equatorial Pacific: a basin scale modeling study. Biogeosciences 6:2647-2660

21. Wang XJ, Behrenfeld M, Le Borgne R, Murtugudde R, Boss E (2009) Regulation of phytoplankton carbon to chlorophyll ratio by light, nutrients and temperature in the Equatorial Pacific Ocean: a basin-scale model. Biogeosciences 6:391-404

22. Boyer TP, Antonov Jl, Garcia HE, Johnson DR, Locarnini RA, Mishonov AV Mitcher MT, Baranova OK, Smolyar IV (2006) World Ocean Database 2005. S. Levitus, Ed.

23. Mongin M, Nelson DM, Pondaven P, Brzezinski MA, Treguer P (2003) Simulation of upper-ocean biogeochemistry with a flexible-composition phytoplankton model: C, N and Si cycling in the western Sargasso Sea. Deep-Sea Research Part I 50:1445-1480

24. Le Borgne R, Landry MR (2003) EBENE: A JGOFS investigation of plankton variability and trophic interactions in the equatorial Pacific (180 degrees). Journal of Geophysical Research 108:8136, doi:8110.1029/2001JC001252

25. Eldin G, Rodier M (2003) Ocean physics and nutrient fields along 180 degrees during an El Nino-Southern Oscillation cold phase. Journal of Geophysical Research 108:8137, doi:8110.1029/2000JC000746

26. Aufdenkampe AK, McCarthy JJ, Navarette C, Rodier M, Dunne J, Murray JW (2002) Biogeochemical controls on new production in the tropical Pacific. Deep Sea Research II 49:2619-2648

27. Matsumoto K, Furuya K, Kawano T (2004) Association of picophytoplankton distribution with ENSO events in the equatorial Pacific between 145 degrees E and 160 degrees W. Deep-Sea Research Part I 51:1851-1871

28. Murray JW, Johnson E, Garside C (1995) A U.S. JGOFS process study in the equatorial Pacific (EqPac): Introduction. Deep Sea Research I| 42:275-293

29. Bissett WP, Walsh JJ, Dieterle DA, Carder KL (1999) Carbon cycling in the upper waters of the Sargasso Sea: I. Numerical simulation of differential carbon and nitrogen fluxes. Deep-Sea Research Part I 46:205-269

30. Spitz YH, Moisan JR, Abbott MR (2001) Configuring an ecosystem model using data from the Bermuda Atlantic Time Series (BATS). Deep-Sea Research Part II 48:1733-1768

31. Shiozaki T, Furuya K, Kurotori H, Kodama T, Takeda S, Endoh T, Yoshikawa Y, Ishizaka J, Matsuno T (2011) Imbalance between vertical nitrate flux and nitrate assimilation on a continental shelf: Implications of nitrification. Journal of Geophysical Research-Oceans 116

\section{Submit your manuscript to a SpringerOpen ${ }^{\odot}$ journal and benefit from:}

- Convenient online submission

- Rigorous peer review

- Immediate publication on acceptance

- Open access: articles freely available online

- High visibility within the field

- Retaining the copyright to your article

Submit your next manuscript at $>$ springeropen.com 